\title{
PARA UNHA INTERPRETACIÓN INTEGRAL DA OBRA ROSALIANA: A «QUESTIONE \\ DELLA LINGUA» 0 PROBLEMA DA(S) LINGUA(S)
}

Xesús Alonso Montero

Universidade de Santiago de Compostela

Real Academia Galega

doi:10.17075/rcsxxi.2014.017 

Digan o que digan os estudosos do feito literario que aínda se declaran antibiografistas, a biografía dun escritor sempre nos axuda a entender mellor a súa bibliografía. Por iso están no certo os autores de libros que se titulan Vida e obra de... Concordes con este criterio, ímonos achegar á biografía de Rosalía de Castro, nomeadamente á súa biografía lingüística. O mesmo habería que facer cos escritores que, máis ou menos contemporáneos de Rosalía, protagonizaron, con ela, o Rexurdimento.

Sen máis preámbulos, o historiador deste feito literario ten que facer, antes de ningunha outra consideración, esta pregunta: En que lingua falaban habitualmente os protagonistas deste acontecer cultural? Xa na década dos oitenta, en pleno acontecer, respondeu á nosa pregunta Emilia Pardo Bazán, unha observadora moi pouco entusiasta da causa galeguista pero moi atinada e sagaz nalgunhas observacións:

Hoy el gallego posee, como el catalán y el provenzal, una nueva literatura propia, pero a diferencia de estos dos romances meridionales, el gallego no lo hablan los que lo escriben (a cursiva é nosa) ${ }^{1}$.

Logo, dona Emilia, nunha famosa velada literaria en homenaxe a Rosalía, celebrada na Coruña mes e medio despois do seu falecemento, achégase á cuestión polo lado da historia:

Débese la superioridad en Cataluña a varias causas bien patentes, entre las cuales descuellan las filológicas. Por culpa de la malaventuranza política de Galicia, el habla gallega vino a quedarse huérfana de la literatura, y la literatura es para las lenguas lima que pule, barniz que abrillanta $[\ldots]$ flor que adorna $[\ldots]^{2}$.

1 «¿Idioma o dialecto?», en De mi tierra, A Coruña, Tipografía de la Casa de Misericordia, 1888, p. 196 (cito pola edición de Xerais, 1984).

2 «La poesía regional gallega» (2-9-1885), en De mi tierra, op. cit., pp. 18-19. 
Liñas despois, a oradora facía unha aclaración, fundamental para entender aquel rexurdir literario e aínda válida, en parte, para achegármonos hoxe á «questione della lingua»:

Al afirmar que el atraso de la lengua gallega nace de su carencia de literatura, no me refiero solamente a las Bellas Letras. También es cultivo literario para un idioma la conversación entre gentes instruidas, el comercio epistolar, la oratoria sagrada y profana, los instrumentos públicos, y en Galicia esto se hace en castellano. No así en Cataluña, donde todas las clases sociales, para todos los usos de la vida, se sirven del habla provincial; por eso allí un leve chispazo bastó a encender la inmensa hoguera de la renaixença literaria $[\ldots]^{3}$.

En efecto - agora falo eu- o «cultivo literario» era, daquela, un mapa caracterizado por ausencias tan numerosas como notables. Non había, nin sequera no medio rural, oratoria sagrada ou profana na lingua dos oíntes; as cartas, subscritas por letrados ou por iletrados, redactábanse no idioma escolar, e as conversas entre as persoas instruídas, aínda tendo estas un certo dominio do galego, eran en castelán, incluso en espazos tan pouco solemnes como a tertulia do casino ou do café. Rosalía e Murguía, que se escribían sempre en castelán, empregaban sistematicamente este idioma, na casa, entre eles e cos seus fillos. Os epistolarios da época que cońecemos, xa bastantes, proban que a lingua do "comercio epistolar» era, sempre, o castelán (Murguía, Pondal, Saco y Arce, Curros Enríquez, Florencio Vaamonde Lores...). Por pouca que sexa a nosa erudición, non imaxinamos a Verdaguer, o autor de L'Atlantida (1877), falando en castelán cos seus sobriños: o Verdaguer que escribiu centos de cartas privadas en catalán, mesmo a persoas instruídas non catalanistas.

Hoxe sabemos que Murguía, nos últimos anos da súa vida, asistía a tertulias compactamente castelanófonas, o Murguía que departía cos seus conxéneres da Real Academia, nas sesións oficiais, no idioma en que el escribía as cartas, que era - lembrémolo — o idioma das actas da institución ata non hai moitos anos.

Así pois, erran totalmente os historiadores da nosa literatura cando, ó abordaren a Renaixença e o Rexurdimento, establecen un paralelismo total. A lingua

3 Op. cit., p. 19. 
que se reivindica nun e noutro renacer é, en Galicia, un idioma moi desestimado, tamén por moitos dos seus usuarios, ademais dun idioma eminentemente rural, alleo a calquera das dimensións da urbanidade, dada a súa condición de fala non atendida polas xentes instruídas da urbe. A sociedade rural de Cataluña, daquela compactamente catalanófona, sabía que, en Barcelona e noutras urbes do seu territorio, o catalán, como fala, reinaba nas casas máis próceres ou cultas. Era o catalán, que aínda se escribía pouco e non se ensinaba na escola, un idioma co predicamento social da «urbanitas».

Hai outra diferenza entre a Renaixença deles e o noso Rexurdimento, termo este que cumpriría substituír por Xurdimento sempre que falemos de páxinas literarias impresas en galego antes de 1880, o ano de Follas novas. Porque cando Rosalía está a compoñer os poemas de Cantares gallegos, entre 1861 e 1863, ela descoñece os textos, no noso idioma, de Martín Codax, Mendiño, Pero Meogo, Airas Nunes e outros poetas do XIII e da primeira metade do XIV, hoxe familiares para os alumnos de bacharelato en Galicia. Nin sequera Manuel Murguía, o seu home, tan erudito no acontecer medieval, tiña noticias precisas, nesta altura, do espléndido corpus poético daqueles dous séculos. Aínda que nesas datas algún que outro poema medieval aparecía pobremente contextualizado nalgunha revista erudita, Rosalía, en 1863, ten a conciencia de que o seu poetizar parte de cero, é dicir, non continúa nin recupera unha tradición literaria ${ }^{4}$. Rosalía ten a conciencia de que está a construír o primeiro libro nunha fala en que nunca se escribira e na que ninguén, no seu tempo, escribía, agás media ducia de nomes, autores duns cantos poemas (Alberto Camino, Francisco Añón, Pintos...), ben pouca cousa

4 Lémbrese, unha vez máis, que a edición — digna de tal nome- dos tres Cancioneiros profanos é moi posterior: Vaticana (1875), Colocci-Brancuti (1880), Ajuda (1904). Cómpre sublińar que Teodosio Vesteiro Torres, antes de suicidarse en Madrid (1876), legou á biblioteca da Universidade de Santiago de Compostela o seu exemplar do Cancioneiro da Vaticana, publicado un ano antes, en Halle (Alemaña), por Monaci. Arredor desta data, xa os máis eruditos, entre eles Murguía, teñen un certo coñecemento da nosa lírica medieval. Sáibase que Murguía, nun artigo de 1858, refírese á Carta Prohemio do Marqués de Santillana con certo escepticismo. Que conste que, once anos antes, Varnhagen xa fixera unha edición do Cancioneiro de Ajuda (Viena, 1849), só cońecida en Europa por moi poucos eruditos.

En canto ás Cantigas de Santa María, «de» Afonso X, que publicou a Academia Española en 1889, algunha que outra deuse a cońecer na revista Galicia, que dirixía Antonio de la Iglesia, xa en 1861 e 1862. Rosalía, totalmente allea —cómpre reiteralo- ó corpus lírico do XIII e do XIV, compón Cantares gallegos coa conciencia de que escribir poemas en galego implicaba beber só en dúas fontes: a fala das xentes populares e as cancións de raíz popular. 
para podermos afirmar que a nosa escritora é un elo dunha verdadeira tradición literaria. En Cataluña, Verdaguer e os seus compañeiros cultivan e reivindican un idioma do que coñecen páxinas moi ilustres do XIII, do XIV, do XV..., entre elas as de Ramon Llull, Ramon Muntaner, Arnau de Vilanova, Francesc Eximenis, Bernat Metge, Joanot Martorell, Ausias March, Jaume Roig...

Se nos asomamos a unha literatura peninsular tan modesta no seu renacer como a vasca, decatámonos de que os escritores euscaldúns parten da fala oral pero non están alleos a textos escritos no seu idioma, moitos lidos ou memorizados na súa infancia: os devocionarios e outros textos relixiosos, entre eles as oracións básicas e os catecismos, fosen católicos ou protestantes. Unha e outra póla do cristianismo occidental sabían ben que, para adoutrinar en non poucos casaríos, máis ou menos monolingües, había que facelo en éuscaro. Nos sínodos daquel territorio abundan os pronunciamentos neste sentido, non así nos galegos, que nunca manifestaron a menor preocupación por vernaculizar os textos básicos da Igrexa.

En efecto, na Galicia posterior ó xv non existen tales textos en galego. Polo que sabemos, ou se rezaba en latín ou se rezaba en castelán, afirmación que non cuestiona a existencia de dúas versións da oración dominical («O noso pai») en galego no ano 1788, por certo en galego unha miguiña pintoresco. Sabido é que foron solicitadas polo eminente filólogo Lorenzo Hervás y Panduro para figuraren nunha obra en que esa oración se ofrecía, para facer comparatismo lingüístico, en máis de trescentos «idiomas y dialectos» ${ }^{5}$.

Sabido é que no ano 1861 imprimiuse en Londres un dos libros máis «raros e curiosos» da bibliografía moderna galega: o Evanxeo de San Mateo traducido (desde o castelán) por un enigmático José Sánchez de Santa María. Financiouno e prologouno o príncipe Luís Luciano Bonaparte, empeñado, nesta altura da súa vida, en promover a versión, a idiomas e dialectos de nula ou escasa tradición impresa, de determinados textos bíblicos, uns de notable extensión, como o Evanxeo de San Mateo, e outros moi breves, como a «Parábola do sementador», tamén traducida ó galego ${ }^{6}$. Así pois, o labor que promove e financia o príncipe

5 Na súa magna obra Saggio prattico delle lingue, Cesena, 1787. V. o meu artigo «Dos versiones gallegas del Padrenuestro en el siglo XviII", Compostellanum, 10, 1965, pp. 355-357.

6 Sobre este tema teño publicados varios artigos e traballos: «Un centenario: el príncipe Luis Luciano Bonaparte y las traducciones gallegas del Evangelio", La Noche, Santiago, 24-12-1959; logo, no Boletín de 
filólogo non pretende levar a «doutrina» á sociedade galega pouco instruída, ós galegofalantes, que, en 1861, rezaban en castelán e en castelán aprendían o Catecismo do P. Astete, un castelán, por certo, con modos idiomáticos do século XVI, data das primeiras edicións. Así pois, mentres non poucos escritores cataláns e algúns vascos escriben, arredor de 1860, na lingua en que rezan e na que os adoutrinan nos oficios eclesiásticos, Rosalía escribe nesas datas nun idioma que nin sequera a Igrexa, cortesá das «divinas palabras», emprega publicamente.

Por conseguinte, este é o mapa lingüístico e literario de Galicia de 1861, 1862 e 1863, os anos en que Rosalía está compoñendo os trinta e dous poemas de Cantares gallegos. Mapa precario, sen dúbida ningunha, extremadamente precario. Aínda así, Rosalía, tan orfa literariamente, concibe e escribe un volume que a autora sabe que vai ser o primeiro libro en «dialecto", denominación presente no prólogo do poemario e noutros textos en prosa de Rosalía ${ }^{7}$. En 1863 Cantares gallegos, o primeiro libro en lingua galega de Rosalía de Castro, hai que entendelo como un xesto cultural insólito e valente, como unha auténtica proeza. Rosalía estaba a emitir un signo, en 1863, mesmo para a mentalidade de moitos letrados da época, inesperado; desconcertante, por tanto. Esta proeza esixe algunha explicación, porque as proezas, tamén na esfera literaria, non poden ser excesivas.

No caso desta proeza é indispensable responder a esta pregunta: ¿Que é o que caracteriza, literariamente, Cantares gallegos, un libro, segundo reza a portada, escrito «por Rosalía Castro de Murguía»? Digamos, nun primeiro asedio, que Cantares gallegos, a pesar do estampado na portada, non é un libro de Rosalía de Castro, daquela unha muller culta (unha letraferida notoria na época) procedente da fidalguía (dos Castro de Padrón) e esposa de Manuel Murguía (xa un polígrafo galego de certa sona). No esencial, esta Rosalía —fidalga, moi instruída e casada cun erudito - non foi a que escribiu en galego os 31 poemas do libro. Dito doutra maneira, foi ela quen os escribiu, pero non desde a súa condición de fidalga, muller moi lida e compañeira dun profesional das Letras; escribiunos desde outra voz, desde a voz de quen se identifica plenamente coa concepción e co sentir das clases subalternas na Galicia rural de mediados do XIX (unha aldeá namorada,

la Comisión Provincial de Monumentos Históricos y Artísticos de Lugo, «El príncipe Luis Luciano Bonaparte en la Lingüística gallega» (7:57/58, 1962, 1-5) e "El Evangelio de San Mateo. Estudio lingüístico de la traducción gallega de José Sánchez Santamaría» (7:59/60, 1963, 210-214). Hai algún posterior.

7 Tamén no mesmo prólogo empregou «lingua». 
unha mendiga, un labrego que emigra, unha campesiña que suspira pola terra natal, unha moza que ten o seu amor na emigración, un soldado analfabeto que se comunica coa súa noiva, etc.). Nunca falan, nestes poemas, persoas dos estamentos nobiliarios, nin persoas de calquera sector da mesocracia: non falan as clases dominantes, ou sexa, non se fala desde a mentalidade das clases dominantes (ricos, funcionarios, profesionais máis ou menos acomodados, representantes cualificados do poder político...).

No libro, pois, non fala, en realidade, Rosalía Castro de Murguía: fala — se don Antonio Machado e Fernando Pessoa mo permiten - un heterónimo, heterónimo que a propia Rosalía nos presenta e define no primeiro poema do libro, que funciona, realmente, como poema prologal e case programático. Quen vai cantar, ó longo do libro, é unha mociña aldeá, unha «meniña gaiteira», e cantará porque alguén lle ofrece «papiñas con leite», «torrexas con mel», «patacas asadas», "un mantelo» e "un refaixo», dádivas moi propias da economía rural nun día de festa. A «meniña gaiteira», engaiolada polos obsequios, cantará na lingua que se lle propón, o galego, que é, neste caso, como diría Heidegger, «a casa do ser». (O mesmo se pode predicar do poeta en «escocés» Robert Burns (1759-1796), mencionado, verbo de Cantares gallegos, por algún reseñista contemporáneo do libro). Sería inauténtico, desde esta concepción poética, escribir en castelán. A «menińa gaiteira», que acepta o convite e que asume a responsabilidade de cantar Galicia «na lengua en que falo», non sempre é alegre e rebuldeira, que iso significa o adxectivo "gaiteira» no texto rosaliano. A «meniña gaiteira» éo, sen dúbida, cando no poema 5 describe, alborozada, a vistosidade das mozas de distintos lugares de Galicia que van á romaxe da Nosa Señora da Barca, pero xa no poema 2 («Nasín cando as prantas nasen») quen fala é Rosa, moza rural tan namorada de Mauro como contrariada por el, obstinado en facer peticións inatendibles por unha muller que vive naquel universo moral. No poema 3 son dúas as «meniñas» que falan: unha vella mendiga e unha mociña á que aquela muller experimentada convence de que non sempre é bo ver mundo. Tamén hai dúas voces populares no poema 4, un dos poemas emblemáticos do libro ("Cantan os galos pró día): o raparigo, un pouco «machista», que solicita, raposeiro, propasarse un pouco, e María, non menos namorada, pero máis gardadora da convención moral en materia sexual, pois ten máis que perder. 
A «meniña gaiteira», poucas veces leda (todo hai que dicilo), non só se transmuta en namorada moi gardadora da súa honra ou en vella que, mentres pide esmola, filosofa cunha mociña nova. Poemas hai en que fala desde a voz dun home, sempre das clases subalternas. Nunha ocasión é un mozo, chamado Farruco do Pombal (núm. 10), que se laia de que a súa namorada, pouco axuizada, perdeu a honra. O poema 13, «Airiños, airiños, aires», está posto tamén en boca dun home forzado a emigrar:

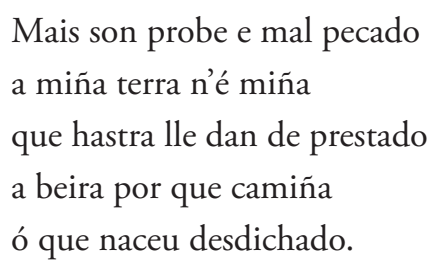

A «meniña gaiteira» agora é un labrego que está farto de pagar o foro ó amo, ou sexa, de traballar terras que non son súas, de traballar para o inglés. A denuncia — da emigración e dos foros - faina Rosalía desde a voz — desde a mentalidade- deste labrego, outro heterónimo da poeta ou, dito doutro xeito, outra das voces da «menińa gaiteira». O que Rosalía pon, neste e en moitos outros poemas, é a poesía, a súa maxistral poesía.

Hai no maxistral libro unha «menińa gaiteira» especialmente dramática, unha moza de aldea que escribe desde a desesperación: é o 25, "Castellanos de Castilla». Quen fala é unha moza namorada que recibe a noticia de que o seu mozo morreu en Castela, na sega, nas duras condicións laborais, climáticas e hixiénicas que soportaban na sega os galegos — os galegos pobres - hai case douscentos anos.

Rosalía non fala desde a súa verdadeira voz, fala desde a voz desesperada, case en situación límite, de quen acaba de perder o amor e, quizais, o futuro. Desde esta dramática situación enténdense interpelacións do tipo «iCastellanos, castellanos / tendes corazón de ferro» ou "Castellanos de Castilla / tendes corazón de aceiro / [...] / e sin entrańas o peito». A «autora» do poema é unha moza do pobo rural educada na idea que xa o pobo, a musa popular, expresara: «Castellanos de Castilla, / tratade ben ós gallegos, / cando van van como rosas, / cando ven, ven como negros». Esta concepción, pouco científica, elude a cuestión esencial: o maltrato non hai que entendelo na pugna etnicista Galicia (fermosa e virtuosa) 
vs. Castela (enxoita e malvada). O problema, como case sempre, é de clase: xente pobre (galegos ou non) procuran o pan fóra da súa terra, onde, sen remisión daquela, quedan nas poutas dos ricos, dos latifundistas, dos empresarios agrícolas que impoñen salario, horario e outras condicións laborais nun tempo e nun espazo nos que non existía ningunha forma de sindicación entre os asalariados do campo. Pero que quede claro que non é Rosalía quen fala. En realidade, o único poema en que Rosalía fala desde a súa voz é un dos últimos, o 28, o que comeza cun "cantar gallego" moi popular nas terras de Iria: "Como chove miudiño». Os menos eruditos detectan estrofas autobiográficas, conmovedoras todas, xa referidas á nai (que xa morrera), xa referidas ó Pazo de Arretén (a Casa grande, noutrora tan hospitalaria), xa referidas a Padrón («ponlińa verde / fada branca ó pé dun río»), a vila da que evoca «o enxidińo onde folgaba» de nena.

Algún lector pode pensar que no poema 9, "Campanas de Bastabales», hai elementos autobiográficos. Eu penso que calquera das outras «menińas» puido sentir emocións semellantes. $\mathrm{O}$ «eu» lírico, que transita polas terras que presiden as badaladas da igrexa de Bastabales, non é, necesariamente, Rosalía de Castro. En realidade, só nunha ocasión o eu poético coincide, claramente, coa persoa Rosalía de Castro: no poema 28, "Como chove miudiño». (Deixamos, para outra ocasión, «A gaita gallega», resposta a unha composición de Ventura Ruiz Aguilera. Responde a esa motivación e aparece, nas dúas edicións feitas en vida de Rosalía, sen número, o que indica que está á marxe da concepción central do libro).

Xa aquí, déixenme imaxinar unha peripecia bibliográfica no Vigo do verán de 1863. Aconteceu na rúa Real, onde o libreiro e impresor Juan Compañel tińa o seu obradoiro tipográfico. Un día de xullo ou agosto dese ano, un avogado moi cońecido e moi culto da cidade entra, curioso, no establecemento do señor Compañel, disposto a adquirir un libro de título insólito: Cantares gallegos. Xurista de moitas lecturas literarias, sospeita que se trata dunha colección de cántigas populares formuladas na lingua dos seus clientes da periferia viguesa. Home moi ó día do que se publica en Galicia, non sospeita que se trate dun volume orixinal enteiramente escrito «en dialecto». Cando o avogado vigués paga os 12 reais que custa o intrigante exemplar, follea, cobizoso, o libro, e non tarda en descubrir que está ante un poemario orixinal non alleo, por certo, ós "cantares gallegos», ás cántigas populares consignadas no título. En efecto, boa parte dos poemas 
de Rosalía de Castro de Murguía glosan un cantar popular galego, e glósano no «dialecto» do cantar.

O avogado vigués, que é un namorado do cancioneiro do pobo, axiña descobre, entre as cántigas glosadas, algunhas das máis fermosas da nosa musa popular. El, non sen emoción, repara nestas:

- Cantan os galos pró día;

érguete, meu ben, e vaite.

- ¿Cómo me hei de ir, queridińa, cómo me hei de ir e deixarte?

***

Adíos ríos, adios fontes, adiós regatos pequenos, adiós vista dos meus ollos, non sei cando nos veremos.

***

Que a rula que viudou xurou de non ser casada, nin pousar en ramo verde, nin beber da iauga crara.

Non se lle escapou ó letrado vigués que esta cántiga, lonxe de encabezar o poema rosaliano, finalizábao, procedemento que a escritora repite nalgunhas outras composicións. Xa na casa, o sorprendido xurista leu boa parte do libro e axiña chegou á conclusión de que, encabezase ou finalizase Rosalía os seus textos con tres ou catro versos de raíz popular, o seu labor poético consistía en contar liricamente unha historia máis ou menos implícita no cantar do pobo, contada sempre desde a concepción moral daquela sociedade rural do século xIx. Para o douto letrado vigués, Rosalía, que «filosofaba» como as xentes do común, o que verdadeiramente puña seu, nos versos do libro, era a poesía, a súa maxistral poesía.

É evidente que o libro de Rosalía agroma nun tempo en que as clases letradas, fillas do espírito romántico, se interesan a fondo polo folclore e, xa dentro do folclore, do saber popular, pola poesía que vive na tradición oral. Ninguén na 
Galicia anterior a 1860 foi máis devoto deste tipo de poesía que Murguía. Xa en 1858 publica un longo artigo que titula «Poesía gallega contemporánea», no que só fala, entre os poetas cultos, de Pintos, Alberto Camino e Francisco Añón, pois, en realidade, moi pouco máis había ${ }^{8}$. Céntrase nos cantos populares no capítulo IV do artigo, onde diserta sobre "poesía popular [...] que forma la atmósfera intelectual de un pueblo, [...] flores que brotaron ignoradas [...], estrellas que iluminan dulcemente el cielo bajo el cual reposamos [...]». Nesas páxinas recolle seis cántigas de alto valor literario, dúas das cales, "Cantan os galos pró día» e "Airińos, airiños, aires», glosaría pouco tempo despois Rosalía de Castro. É neste artigo onde Murguía atribuía a composición de parte do noso cancioneiro popular á muller «mientras se dedica a las faenas domésticas», idea que xa no XVIII expresara con elocuencia o P. Sarmiento. Este é o Murguía que, meses despois, casa con Rosalía e que, desde ese mesmo momento, lle transmite o seu interese, o seu compromiso, coa poesía popular. Rosalía non só se interesa polas cántigas do pobo, vai máis alá: recólleas, examínaas con suma atención e, feito isto, opta, non por escribir cántigas ó xeito popular, como fixo Augusto Ferrán no seu idioma, si por escribir poemas suscitados polo espírito desas cántigas, que, alén diso, reproduce. É a propia Rosalía quen, no prólogo do libro, confirma a súa vinculación ós «nosos cantos populares». Engade, despois de sinalar que só aprendeu na «escola dos nosos probes aldeáns», que para compoñer o libro estivo «guiada solo por aqueles cantares».

No final do limiar aclara que puxo «o maior coidado en reproducir o verdadeiro esprito do noso pobo». Así foi, se se entende por pobo, neste caso, o espírito das clases subalternas na Galicia rural de 1868. Así pois, a propia Rosalía, no seu importantísimo prólogo, recoñece claramente que non bebe noutra fonte senón na da poesía popular. Anos despois, Murguía, moi consciente do precario punto de partida da nosa escritora, escribía:

Por fortuna, el cielo se apiadó de nosotros y aparecieron los primeros versos verdaderamente gallegos con que una mujer — no necesito decir su nombre, pues está en vuestros labios-

8 El Museo Universal, Madrid, 28-2-1858 e 30-3-1858. 
realizó el milagro de levantar nuestro espíritu popular y dar a Galicia una lengua literaria y consagrar con ella una nacionalidad 9 .

Aínda non está claro como Rosalía concibiu o libro na súa totalidade nin en que datas escribiu 26 dos 31 poemas que o constitúen, pois de cinco coñecemos os anos da súa primeira edición (un, en 1861, e catro, en 1862) ${ }^{10}$. Murguía, que se implicou a fondo na motivación de Cantares gallegos, pronunciouse, bastantes anos despois, sobre o proceso de composición e edición do libro, proceso do que nos deixou «dúas versións algo distintas», como ben sinalou, hai pouco, Xosé R. Barreiro Fernández ${ }^{11}$. En Los precursores, de 1885, afirma:

Impreso el primer pliego de los Cantares, sin que de ello tuviese noticia, viose obligada a escribir el resto del libro a medida que las cajas demandaban original. Aprisa, sin dar tiempo a que secasen las cuartillas, sin corregir ni leer al día siguiente lo escrito la víspera, fecunda, abundante, espontánea sobre toda ponderación, fue dando hoy una, mañana otra, la mayor parte de las composiciones que forman aquel pequeño volumen ${ }^{12}$.

Pouco antes do seu falecemento, Murguía nunha carta explicaba:

[...] en sus momentos de descanso fue escribiendo las composiciones que aparecen en sus Cantares gallegos, los cuales, sin que ella lo supiera, llevé a Vigo y di a la imprenta de mi buen amigo Juan Compañel. De esto nada supo mi esposa, hasta que terminada la impresión del libro se lo envié para que me remitiese el prólogo. Negóse a ello, empeñada en que era mejor saliese con mi nombre y pasó un mes largo sin que se rindiera, hasta que al fin los gastos hechos la obligaron ${ }^{13}$.

Eu acredito máis na primeira versión, escrita no ano en que morreu Rosalía, quen, de vivir uns meses máis, lería este texto. Da segunda versión, é moi pouco crible que Rosalía renunciase a autoría do libro a favor do seu home, poeta máis

9 [Elogio de Curros Enríquez], BRAG, 70, 1-3-1913, p. 262.

10 En El Museo Universal, Madrid, 24-11-1861, publicou "Adiós, que eu voume», logo, no libro, sen título e encabezado pola copla "Adiós ríos, adiós fontes». Así, con este título, aparece no Álbum de la Caridad, de 1862. No famoso Álbum publicouse por primeira vez "Castilla» (coa copla "Castellanos de Castilla»), "O caravel negro», «A romaría da Barca» (sen a copla inicial), «iTerra, a miña!» (coa copla inicial "Airiños, airińos, aires»). Repare o lector na circunstancia de que os cinco poemas anteriores a 1863, no volume de Compañel, non teñen título, e dous carecen de copla inicial.

11 Murguia, Vigo, Galaxia, 2012, pp. 260-263.

12 A Coruña, Biblioteca Gallega, 1885, pp. 187-188. (Hai edición facsimilar, A Coruña, Editorial La Voz de Galicia, 1975).

13 Esta carta, en fase de borrador, exhumouna Juan Naya Pérez no seu artigo "Murguía y su obra poética» (BRAG, 1946-1950). V. op. cit., p. 262, n. 96. 
ben discretińo que tería que suprimir do volume os cinco poemas xa editados co nome de Rosalía, tres tan significativos como «Castellanos de Castilla», «Airiños, airiños aires» e «Adiós ríos, adiós fontes».

O que, si, penso é que Murguía presionou, ás veces en exceso, para que Rosalía compuxese canto antes, desde fins de 1861, un volume na liña dos cinco poemas xa cońecidos, catro dos cales aparecían vencellados a versos da musa popular, a musa que obsesionaba a Murguía desde había algúns anos. É moi probable que Compañel comezase a imprimir os primeiros pregos instado por Murguía, que, deste xeito, influiría con máis eficacia sobre a escritora para que escribise un volume de certa entidade. Algo orienta sobre esta cuestión a prepublicidade do libro, da que é responsable Compañel, o editor e impresor. Nun anuncio fálase dun "precioso volume en $8^{\circ}$ francés [...]. Precio de cada tomo, 16 reales en la Península, en La Habana, 30» ${ }^{14}$. Nun anuncio posterior, tamén de 1862, segue a falarse dun «volumen en $8^{\circ}$ francés», pero agora o prezo é de « 12 reales», quizais porque a extensión é menor, aínda así «de cerca de 300 páginas» ${ }^{15}$. O certo é que, se examinamos o volume impreso por Compañel, consta de 188 páxinas, delas só 172 dedicadas á poesía (as outras 16 abranguen o "Glosario", as dúas páxinas de «Erratas notables» e dúas de «Índice»). Cabe sospeitar que Rosalía non tivo folgos, en tan pouco tempo e tan presionada, para escribir uns cantos poemas máis, tantos como para completar o volume de 300 páxinas. Aínda hai outro dato que nos revela que, no proceso de composición e edición do libro, o editor e o mentor (Murguía) tiñan un plan que quizais non coincidía co da autora. Na primeira edición, despois das páxinas do prólogo, numeradas en romano, hai unha folla, sen numeración, na que se consigna PIRMEIRA PARTE, e a continuación figuran as páxinas que conteñen a totalidade dos poemas, numerados aquelas e mais estes en arábigo. Esta «Pirmeira parte» indica que, no mesmo volume, se chegase a ser de 300 páxinas, habería unha segunda parte? Non é descartable que o mentor e o editor pensasen nun segundo volume de Cantares gallegos que acollese os poemas dunha «Segunda parte». Convén aclarar que o rótulo «Pirmeira parte» non figura na segunda edición do libro, a de 1872, feita en vida de Rosalía. Os datos aducidos demostran que Rosalía traballou no libro moi condicionada

14 Na tapa do Diccionario de escritores gallegos, de Murguía, Juan Compañel Editor, 1862.

15 En Galicia. Revista Universal de este Reino, A Coruña, 15-8-1863. 
polo impresor e polo mentor da operación, artífices dun plan editorial ó que ela, quizais, estivo allea. Con todo, no esencial, Murguía cumpriu o seu obxectivo rexeracionista: ofrecer a aquela Galicia tan pouco comprometida coa galeguidade o primeiro libro en galego, un libro, por outra parte, moi vencellado á poesía popular do país, unha das teimas do historiador, e unha colección de poemas de altísima valía literaria, porque Murguía, na medida en que podía ser obxectivo, estaba moi convencido da categoría estética de Rosalía de Castro.

Aquí as cousas, cómpre afirmar que, sen os consellos e as premas de Murguía, non existiría un libro que foi peza fundamental para a operación rexeracionista por el ideada e, en boa parte, protagonizada por el. Nesa operación Rosalía concibiu un libro que se abre co poema da «meniña gaiteira», a musa convidada e disposta a cantar, a mesma musa que no poema 31, o epilogal, confesa que cantou con pouca "grasia» se ben recońece que é moi grande «o amor da patria». Neses dous anos escasos en que Murguía aprema a Rosalía de Castro para que cante co seu talento e co seu amor á patria, esta foi compoñendo estampas do vivir popular de Galicia e inseríndoas entre eses dous textos indispensables, o 1 e o 31, incluso, cando en 1872, engade - intercalándoos - catro novos poemas. Poemas, os 35, que Rosalía foi creando, máis ou menos presionada por Murguía, como se de capítulos se tratase dunha epopea lírica do pobo galego, como se de fragmentos do seu existir se tratase: eran Rerum vulgarium fragmenta, que así denominou Petrarca o seu celebérrimo Cancioneiro, obra escrita no vulgar toscano e non no excelso latín en que escribira outras obras súas. Rosalía, en 1863, abandona o latín de La flor e de A mi madre e achégase, no vulgar do país, a fragmentos significativos da biografía rural galega, e faino desde un punto de vista incompatible cunha lingua que non fose a dos seus protagonistas. Nesa hora, a do 17 de maio de 1863, cantou a cotovía e o galego comezou a ser un volgare illustre.

En 1858, Murguía, despois de examinar o mapa da poesía galega, constituído pola canción popular e algunhas (moi poucas) manifestacións cultas, conclúe:

Los que escriben en este dialecto, tienen que hacer hablar a sus héroes, y estos no pueden ser nunca más que aldeanos; los de las ciudades creerían verse puestos en ridículo el día que se les presentara hablando el dialecto en que hablaron sus abuelos y que hoy les avergüenza. El poeta, pues, tiene que ceñirse a un solo objeto y girar en un estrecho 
círculo. La vida del campo, las costumbres de los aldeanos, la égloga, en fin, es lo único que le es permitido $[\ldots]^{16}$.

Cinco anos despois, a súa muller, Rosalía de Castro, publicaba un libro de «églogas» en que os seus heroes eran «aldeanos». Rosalía — repito unha idea xa formulada neste traballo_ - escribía desde a aldeá que levaba dentro, desde ese heterónimo. Xa don Miguel de Unamuno, en 1912, reparara, referíndose a Rosalía de Castro, na súa condición de aldeá: «Aquella pobre aldeana —pues siempre lo fue Rosalía — llevando la vega de Padrón en el alma [...]» ${ }^{17}$.

\section{ROSALÍA E O IDIOMA GALEGO ENTRE 1863 (CANTARES GALLE- GOS) E 1880 (FOLLAS NOVAS)}

Nestes 17 anos, período non moi breve, a nosa escritora publica dous cadros de costumes («El cadiceño», "Las literatas») e dúas novelas (Ruínas, 1866, e El caballero de las botas azules, 1867). Son novelas en castelán, xénero non intentado daquela en galego. Non estaba indotada Rosalía para o relato longo, pero é claro que aínda os seus mellores títulos non poden competir cos inicios, como narradores, de Benito Pérez Galdós, Juan Valera, Emilia Pardo Bazán, Clarín e algún outro. Eu estou convencido de que Rosalía sentíase, fundamentalmente, poeta; agora ben, fixo non poucas incursións no eido da novela porque, non carecendo de virtudes narrativas, era un xénero máis lucrativo. Non esquezamos que, nunha economía como a de Rosalía-Murguía, con frecuencia un pouco precaria, era preciso explorar outras fontes de ingresos. Rosalía, consciente de que a poesía producía moi pouco, escribiu novelas, non sempre publicadas en volume senón por entregas en revistas, procedemento prodigado na época tamén por razóns económicas. Incluso unha, Flavio, asinouna R. de Castro, quizais para ocultar a súa identidade feminina, para moitos pouco comercial ${ }^{18}$.

16 Op. cit. na n. 2.

17 «Santiago de Compostela». Escrito en agosto de 1912, Unamuno incorporouno ó volume Andanzas y visiones españolas (1922). Cito por Obra completa, I, pp. 580-583.

18 Non teño en conta o "Conto gallego» (1864), atribuído a Rosalía, porque aínda para os críticos é causa de litixio. Hai unha edición que reproduce a aparecida en El Eco Ferrolano no ano 1868 e que quizais incline os especialistas 
Neste período, os textos galegos de Rosalía son textos en verso. Catro deles, intercalándoos entre o 1 e o 31 (agora 35), incorpóraos á segunda edición de Cantares gallegos (Madrid, 1872). Son poemas que responden de cheo á concepción rosaliana de 1863, tan grata a Murguía. Ignoramos en que datas, entre 1863 e 1872, se escribiron estes catro poemas, cuestión para nós, neste estudo, irrelevante.

Non é irrelevante en que momento a nosa escritora fai incursións poéticas en eidos alleos ós de Cantares gallegos. Ten data a primeira, 1865, o ano en que publica a tradución galega duns textos líricos do poeta salmantino Ventura Ruiz Aguilera, escritor moi relacionado con Rosalía e, aínda máis, con Murguía ${ }^{19}$. Como poeta esforzouse en que algunhas das súas composicións fosen traducidas a un número considerable de linguas, traducións que el mesmo solicitaba ós amigos e que incluía nalgunhas edicións dos seus libros. Nun destes, Armonías y cantares (1865), publica 25 «cantares» na versión de Rosalía e a tradución de «Ruínas (Armonías de la tarde)». Os «cantares» (case sempre de catro versos) son -en Ruiz Aguilera - un tributo a unha arraigada moda daquel tempo: o gusto pola cántiga popular e polos textos breves do Libro das cancións (Buch der Lieder, 1827) de Heinrich Heine (1797-1856), poeta que tamén influíu sobre Bécquer. Lémbrese que un prebecqueriano como Augusto Ferrán, no seu libro máis significativo, La soledad (1867), ofrécenos cantares non só inspirados en Heine senón tamén no cancioneiro popular, do que é tan devoto que, nunha especie de prólogo, reproduce un número considerable deses cantares populares.

A Rosalía que traduce vinte e cinco "cantares» de Ruiz Aguilera non glosa cántigas do pobo, como en Cantares gallegos, pero non está lonxe da poética que os inspirou. Está moi lonxe no poema «Ruínas», unha meditación, tamén moi rosaliana, sobre a existencia invernal. O poema concorda con non poucas páxinas de Follas novas, libro en que acolleu esta tradución feita quince anos antes. Pero tanto o poema «Ruínas» como os 25 «cantares» non xorden motu proprio, foron

a atribuíren o peculiar relato á nosa escritora. V. o prólogo de Xesús Torres Regueiro a esta edición: Contos da miña terra, por Doña Rosalia Castro de Murguía, Betanzos, Asociación Cultural Eira Vella, 2012.

19 En Armonías y cantares, 2a edición, Madrid, Imprenta M. Guijarro, 1865. 
traducións solicitadas por un amigo ó que era moi difícil non compracer: foron obras de encarga ${ }^{20}$.

Chegou a hora de asomármonos ó segundo libro de Rosalía, Follas novas, impreso en 1880. Importa saber en que datas se escribiron a maioría dos seus poemas; segundo Murguía, nos anos 1870 e 1871, afirmación que avalan unhas lińas do prólogo da autora:

Máis de dez anos pasaron — tempo cásique fabuloso a xuzgar pola presa con que hoxe se vive - desque a maior parte destes versos foron escritos, sin que contrariedades da miña vida desasosegada, e unha saúde decote endebre, me permitise apousar neles os meus cansados ollos i o meu fatigado esprito.

Avala esta cronoloxía a contraportada da segunda edición de Cantares gallegos (1872), onde se anuncia, como próxima, a publicación de Follas novas. Hai que supoñer que a autora, nesta altura, xa escribira un número considerable de poemas do novo libro, se ben o volume tardou seis anos en aparecer. Eu parto do feito, en efecto, de que o esencial do segundo libro galego de Rosalía estaba escrito en 1872.

O novo libro, as novas follas, están moi lonxe da concepción e do espírito de Cantares gallegos, publicados nove anos antes. Está moi lonxe, por conseguinte, daquel libro «folk» de 1863, daquel poemario en que trazou a epopea lírica do existir rural galego ${ }^{21}$; do libro en que, transmutada en aldeá, cantou as peripecias, os amores, as coitas, as carraxes, as devocións e as picardías das xentes subalternas do mapa non urbano da Galicia do XIX. Esa era a cosmovisión daquel libro auroral tan vencellado ó cancioneiro popular e á estratexia galeguizadora do seu home, don Manuel Murguía.

20 Sobre as distintas edicións de «Ruínas» e as súas variantes, v. «Versións de "Ruínas”, apéndice V da edición de Follas novas feita por Henrique Monteagudo e Dolores Vilavedra, Vigo, Galaxia, 1993.

21 Non é a primeira vez que neste traballo, ó referirme a Cantares gallegos, o conceptúo como unha «epopea lírica do existir rural galego», idea non allea a unha formulada por Murguía en 1885: «Y en verdad que sin la precipitación con que fue escrito este libro, cegadas ciertas lagunas y dispuestas y enlazadas las composiciones de un modo tal que formasen un todo correlativo, como así lo había pensado, hubiéramos tenido desde entonces un afortunado equivalente de Mireya [...] (Los precursores, p. 192). 
Pero nestes nove anos, Rosalía meditou a fondo sobre a súa condición de poeta e sobre o tipo de poesía á que ela se debía. Por iso abre o primeiro libro de Follas novas «Vaguedás», con cinco poemas que son outras tantas incursións na súa poética, na súa maneira de entender a poesía. Tense citado mil veces un destes cinco poemas programáticos e non será inútil citalo unha vez máis:

Daquelas que cantan as pombas $\mathrm{i}$ as frores, todos din que teñen alma de muller.

Pois eu que n'as canto, Virxe da Paloma, ¡ai!, ¿¿de qué a terei?

Nestes catro versos xa nos adianta que o seu canto está ditado por outras musas, que o seu meditar poético non concorda co das poetisas á usanza. Noutros poemas do programático pentateuco inicial, xa se define como autora de «versos [...] que ten estrana, insólita armonía». Xogando co adxectivo do título, Follas novas, aclara que tales follas son «irtas, como as miñas penas / feras, como a miña dor», e non podía ser doutro xeito por brotaren da "gándara» do seu espírito.

Nese primeiro libro non escasean os poemas en que a escritora alude á dramática situación existencial desde a que escribe a súa poesía, situación que xa define no prólogo cando recoñece que «o meu libro de hoxe [foi], escrito, coma quen di, en medio de tódolos desterros». Liñas antes afirmara que os poemas do libro foran «Escritos no deserto de Castilla, pensados e sentidos nas soidades da natureza e do meu corazón», texto que nos permite entender mellor «os desterros» da primeira afirmación. É evidente, para min, que non alude ó desterro físico en Castela senón a desterros máis graves, máis esenciais, un deles o sentirse fronte á súa «soidade». E aquí fainos un aceno a pluma de Ramón Piñeiro, quen definiu a saudade como o sentimento da soidade ontolóxica do ser humano, como a vivencia sentimental que os seres humanos teñen da súa soidade en relación ó Ser ${ }^{22}$. Rosalía, que sentiu diversas morriñas (da patria, da nai, dos fillos...), algunhas veces expresou o que ninguén expresara antes na poesía española: o desamparo

22 En «Siñificado metafísico da Saudade» (Colección Grial, 1, Vigo, Galaxia, 1951, pp. 5-25) e «A saudade en Rosalía» (7 ensayos sobre Rosalía, Vigo, Galaxia, 1952, pp. 95-109). 
total do ser humano, a súa radical orfandade, a súa noite existencial. Piñeiro selecciona, entre outros, estes versos:

Só en min mesma buscando no escuro

i entrando na sombra

vin a noite que nunca se acaba

na mińa alma soia.

Para atoparmos exploracións poéticas semellantes na lírica peninsular do XIX habería que pensar nos sonetos de Antero de Quental.

Rosalía nestes e noutros poemas mergúllase en esferas da súa intimidade que nada teñen que ver co libro de 1863. Abondaría con citar, por seren moi coñecidos, "Unha vez tiven un cravo", "Na catedral», "Cando penso que te fuches», "Estranxeira na súa patria», "O encanto da pedra chan», etc.

Hai tamén unha Rosalía que, ás veces, fóra das fauces angustiosas da saudade, compórtase como un ser humano aberto ás realidades morais e sociais inmisericordes, o que provoca, polo menos nunha ocasión, unha resposta que non ten par na poesía española do seu tempo. Refírome a ese poema grandioso, "A xusticia pola man», que é a poetización excelsa da violencia total provocada nun ser humano, nunha muller, á que os poderes —incluso os suprahumanos_ parecen non deixarlle outra saída.

É a Rosalía que manifesta ter, nalgunha ocasión, unha percepción angustiada das realidades meta-físicas:

\section{Teño medo dunha cousa}

que vive e que non se ve.

Páxinas moi valiosas de Follas novas son os textos que a crítica do xx denominou poesía social, e dentro desas páxinas cómpre subliñar o libro $\mathrm{V}$, axeitadamente titulado "As viúdas dos vivos e as viúdas dos mortos», no que a denuncia da emigración está ditada polas musas da com-paixón. En efecto, Rosalía - como aclara no prólogo— sente «as súas penas como si fosen miñas». Hai, nese quinto libro, un poema excepcional, cun comezo inesquecible: 


\begin{abstract}
Tecín soia a miña tea,
sembrei soia o meu nabal, soia vou por leña ó monte, soia a vexo arder no lar.
\end{abstract}

Para esta aldeá pobre, que ten o home nas Américas, as noites son moi duras, sobre todo nos mementos en que

ferve o pote..., mais, meu caldo

soiña te hei de cear.

Non fai falta que Rosalía o explique: hai anos esta muller comía o caldo, ó pé do lume, na compaña do seu home. Aínda na pobreza, había compaña física e había a compaña das palabras arredor dunha sinxela cunca de caldo. É o drama da soidade física e da soidade vital, que quizais non teña fin. Quen fala non é Rosalía, é a aldeá que «tece soia a tea» do seu vivir coa que a nosa escritora com-padece.

Non pretendemos neste apartado trazar o mapa completo dos temas e das actitudes presentes en Follas novas, onde, por certo, hai algúns poemas magníficos que ben podían figurar en Cantares gallegos. O que pretendemos é apuntar que estamos ante un volume heteroxéneo, moi rico en temas e con páxinas dunha fondura lírica insólita, alén de incursións na realidade que constitúen unha interpelación inédita desa realidade. Se Rosalía entre 1861 e 1863 aplicou a súa musa —unha das súas musas - á estratexia esbozada por Murguía, agora, moi consciente da súa valía como poeta, decide oír a súa verdadeira voz, a súa voz máis fonda, máis radical. Escribe, pois, desde o ortónimo e, cando apela a un dos heterónimos, como en "Tecín soia a miña tea», a voz que escoita é a dun ser humano da nación sociolóxica dos de abaixo que emite unha queixa que é, asemade, denuncia dun esquema socioeconómico moi pouco humano. As mozas campesiñas de Cantares gallegos non emitían esta revelación.

Estamos, pois, ante un libro dunha magnitude, dunha fondura, dunha riqueza e dunha ambición insospeitables, en 1880, para un libro «en dialecto». Un libro, por outra parte, no que a nosa escritora mergullaba o dialecto nos socalcos máis problemáticos da condición humana cando as máis diversas circunstancias poñen a proba esa condición. 
Foi Alfredo Vicenti o autor da recensión contemporánea máis valiosa e orixinal de Follas novas, recensión da que non me resisto a reproducir este xuízo:

Excede este en grandeza de miras, en originalidad y en contextura a todos los productos contemporáneos de la lírica española (Bécquer, Campoamor y Núñez de Arce inclusive) $[\ldots]^{23}$.

Esta é a proeza que protagoniza «en dialecto» Rosalía de Castro no ano 1880. Entre 1863 e 1880 (un período de dezasete anos), ningún dos poetas galegos preludiaba un suceso literario destas características, desta magnitude e desta entidade poética, nin sequera Valentín Lamas Carvajal, elo fundamental entre Cantares gallegos e os libros que aparecen en 1880, «annus mirabilis» da poesía galega.

Nese ano estréase, como poeta con libro, unha das voces máis valiosas do acontecer galego do XIx e do Xx, a do autor de Aires da miña terra, pero Curros Enríquez, o gran Curros, inmenso como musa cívica, non compón un volume da grandeza, da riqueza e da fondura existencial de Follas novas.

\section{DA DIMISIÓN DE ROSALÍA (PRIMEIRA PARTE)}

Na páxina final do prólogo de Follas novas, Rosalía, consciente da boa acollida do libro Cantares gallegos, comprende que estaba «obrigada a que non fose o primeiro e o último» na nosa lingua, pois "N'era cousa de chamar as xentes á guerra e desertar da bandeira que eu mesma había levantado». Rosalía, nesta declaración, revélanos, sen fachenda, que Cantares gallegos foi a bandeira desa operación cultural que a posterioridade chamaría Rexurdimento. Rosalía, pois, é consciente do significado auroral do seu primeiro libro en galego. Pasado bastante tempo, decide publicar un segundo libro en lingua galega, pois, de non facelo, ela, que iniciara a guerra, desertaría.

Parece claro que o éxito de Cantares gallegos comprometeuna civicamente a ofrecer un novo volume de poemas en idioma galego, o que está a prologar. Non desertou, por tanto; non arriou a bandeira que ela izara, en grande, por primeira

23 La Ilustración Gallega y Asturiana, 27, 28-9-1880, p. 340. 
vez. Tal declaración impresionou o escritor e patriota cubano José Martí en 1891, quen foi capaz de escribir:

[...] no me queda más remedio, siendo como soy quien de público he alzado por ella bandera, que decir como la poetisa gallega Rosalía de Castro, al publicar su segundo tomo de versos en dialecto: «N'era cousa de chamar $[\ldots] »^{24}$.

Rosalía escribe estas palabras en Santiago o 30 de marzo de 1880, e é nese prólogo onde, poucas lińas despois, dá a entender que non volverá enarborar a bandeira de 1863. Esta é a súa inquietante declaración:

Alá van, pois, as Follas novas, que mellor se dirían vellas, porque o son, e últimas, porque pagada xa a deuda en que me parecía estar coa miña terra, difícil é que volva a escribir máis versos na lengua materna.

¿Por que esta declaración de intencións? O que anuncia Rosalía, nestas palabras que ninguén lle demandou, é algo moi grave: que ela xa non será un soldado da causa, unha voz ó servizo da construción dun discurso literario que ela iniciara, con brillantez, en 1863: un discurso — cómpre engadir- ó que ela, dezasete anos despois, facía unha achega moi importante, moi valiosa, esencial.

Ignoramos se ela o consideraba así. Ela cumpría con ofrecer ós lectores de Cantares gallegos un segundo libro na mesma lingua. Que non se sentise obrigada a ofrecer un terceiro libro na lingua do país, ‘a que obedece? Hai que supoñer que Rosalía non é optimista sobre o futuro do idioma, un idioma, nesa altura, só posto a proba, e poucas veces, no eido da poesía. Ela — penso eu— non se ve contribuíndo a construír un discurso literario de tan limitado horizonte. Na súa consideración nin sequera percibe o papel que o seu segundo libro pode desempeñar como incitación. En calquera caso, nós, hoxe, temos que manifestar a nosa estrañeza ante a intención da autora de abandonar o cultivo literario do galego.

24 Carta a Vicente G. Quesada en Obras completas, vol. 20, A Habana, Editorial de Ciencias Sociales, 1991, p. 493 (V. o meu art. "José Martí e Rosalía de Castro: un texto e un enigma», en Varios, Martí, palabra de liberdade, Oleiros, Comité Galego de Honra Pro CL aniversario do nacemento de José Martí, 2003, pp. 61-63). 
Esta estrañeza xa a formulou un contemporáneo de Rosalía, Alfredo Vicenti (na recensión citada):

A punto de terminar, asáltanos un mal recuerdo: el de la desengañada manifestación hecha por la señora Castro de Murguía al final de su prefacio: «Alá van, pois, as Follas novas $[\ldots] »$.

Dios y Galicia, ya que no nuestras súplicas, harán que no se cumpla la amenaza ${ }^{25}$.

Cumpriuse, sen que ninguén, durante décadas, intentase algún tipo de explicación. Eu sigo pensando que a decisión de arriar a bandeira, a decisión de negarse a producir en galego, está intimamente vencellada ó contexto da época, mesmo ó contexto máis próximo, no que aparece, xa poderosa, a figura de Murguía.

Deste Murguía de 1880 moi pouco sabemos, nomeadamente da súa relación literaria e política con Rosalía, a súa muller. Que se saiba, ela nunca revelou cal foi o contido das súas conversas con Murguía sobre as Belas Letras e as perspectivas do galego como idioma literario, e, en canto a Murguía, nunca, se nos atemos á monumental biografía de Barreiro Fernández, aclarou cales eran as preocupacións íntimas de Rosalía sobre eses dous temas e, en xeral, sobre a causa galeguista, causa da que, naquela altura, don Manuel era o máximo definidor, historiador e propagandista. Ben sabido é que Murguía, sempre que se refería a Rosalía, ou ocultaba importantes datos ou esmerábase nas formulacións vagas e imprecisas ${ }^{26}$; tamén sabemos que destruíu e mandou destruír cartas, sen dúbida, de gran valor documental.

Así pois, estamos moi lonxe de asistir a unha conversa entre o Sabio e a Poeta sobre a cuestión da galeguidade e sobre o porvir do galego como lingua literaria. Non ignoramos, con todo, o que pensa Murguía sobre esta problemática, pensamento que, á forza, tiña que condicionar, dalgún xeito, á Rosalía escritora. Chegou a hora de afirmar que Murguía, xa daquela home de Letras de notorio predicamento en Galicia, posuía un ideario lingüístico (e un comportamento idiomático) pouco estimulantes para os escritores que tiñan, daquela, un certo

25 Op. cit. na n. 23.

26 X. R. Barreiro Fernández cita unha carta súa de 1868 na que conta unha anécdota non susceptible de elevala a categoría: «Una vez intenté ser diputado a Cortes [...]. Mi mujer, que no veía con gusto la política, me hizo desistir» (p. 329). 
compromiso co cultivo do galego. Penso que é útil ofrecer seis pronunciamentos ós que acompañan senllas breves glosas miñas.
a. En 1879

De antiguo se sabe que donde hay lengua diversa hay diversa nacionalidad [...]

(«Desaparecerán los dialectos?», La Ilustración Gallega y Asturiana, 30-7-1879)

Barreiro Fernández, ó reproducir este texto, comenta:

[...] Murguía o que pretendía era [...] deixar clara a relación entre lingua e política (p. 408)

b. En 1880

Amemos, pues, nosotros lo nuestro. Aprendamos y cultivemos el dialecto gallego, porque si hay algo vivo en un pueblo $[\ldots]$ es su lengua. No hagamos como los irlandeses, nuestros infortunados hermanos, que maldicen en inglés de la tiranía de Inglaterra. Imitemos a los del País de Gales, que según la feliz expresión de H. Martin, dicen en cymrico que no quieren ser más que cymros.

(«Inédito del P. Sarmiento», La Ilustración Gallega y Asturiana, 28-3-1880)

c. En 1891, nos Xogos Florais de Tui

O noso idioma, o que falaron nosos pais e vamos esquecendo, o que falan os aldeáns e nos achamos a ponto de n'entendelo [...]

Léngoa distinta — di o aforismo político— acusa distinta nacionalidade.

É a única achega do autor, de certa entidade, ó cultivo do galego. No mesmo evento — xa non ante «os aldeáns» senón «inter pares» —, no discurso de despedida, Murguía falou en castelán. 


\section{d. En 1906, no Discurso de inauguración da Real Academia Galega}

[...] pueblo que olvida su idioma es un pueblo muerto (p. 126). Gentes que hablan la lengua que no les es propia, es un pueblo que no se pertenece (p. 128).

(BRAG, 20-11-1906)

Xa en 1859, na primeira lección («Del dialecto») do libro de lectura para as escolas de primeiras letras de Galicia La primera luz (Vigo, Compańel), adoutrinaba:

Amad el lenguaje en que hablamos todavía; jel pueblo que olvida y escarnece su idioma, ese pueblo dice al resto del mundo que ha perdido su dignidad!

e. En 1906 no discurso de resposta ó de ingreso na Academia de Parga Sanjurjo

Y pues la lengua gallega vive entre nosotros y se habla, estudiémosla, amémosla y afirmémosla como la cosa más nuestra que conservamos del pasado.

(BRAG, 20-11-1907, p. 109)

Neste acto, da Real Academia Galega, insta a estudar, amar e afirmar a lingua galega, pero parece que non convida os asistentes ó acto a falala e a escribila.

En 1908, Celso García de la Riega, que non lle quería ben a Murguía, sobre todo ó historiador, repróchalle, non sen razón, certas incoherencias:

[...] ni conoce nuestro idioma [...] ni lo ha estudiado ni lo ha usado, es decir, que la patriótica obra [...] la hiciesen los demás. Un capitán araña! Un calvo pregonando su específico para que brote el cabello! ${ }^{27}$.

27 Figura na compilación de «Ramón Erotiguer» (José María Riguera Montero) Películas académicas..., A Coruña, 1908. O texto aducido reprodúceo Barreiro Fernández, op. cit., p. 605. 
f. En 1910 nun «Mensaje de la Academia»

[...] siendo un aforismo que lengua distinta, distinta nacionalidad, conservando la que nos es propia, afirmamos la personalidad de nuestra región.

(BRAG, 31-12-1960, p. 121)

Con este home, con este polígrafo, con este galeguista, compartía Rosalía lume e leito, e nos últimos anos non houbo, na vida de Rosalía, persoas do mesmo universo intelectual que tivesen con ela relación que non fose esporádica, moi circunstancial. En 1880, pois, Murguía, só Murguía, como circunstancia cultural (no sentido orteguiano), é a única circunstancia importante, por non dicir única. Condicionada por esa circunstancia, non nos estraña que Rosalía non se sinta moi comprometida a seguir escribindo «en dialecto»; farao en castelán, idioma, por outra parte, no que Rosalía, Murguía e os seus fillos xantan, xogan, rezan e sachan a horta da casa da Matanza.

A Rosalía que anuncia a súa dimisión o 30 de marzo de 1880 é a escritora que vive a carón deste Murguía que adorna as súas contradicións idiomáticas cunha retórica, ás veces, brillante; tamén é a Rosalía que non é moi consciente da grandeza, da riqueza e da orixinalidade do libro, Follas novas, que nos está a ofrecer.

\section{DA DIMISIÓN DE ROSALÍA (SEGUNDA PARTE)}

Se o 3 de marzo de 1880 Rosalía de Castro ameaza (como diría Alfredo Vicenti) con non volver escribir versos en "dialecto", un ano e catro meses despois (o 26 de xullo de 1881) declara, nunha carta ó seu marido, «mi resolución de no [...] escribir en gallego». ¿Que acontecera neste período? En principio, hai algo, acontecido no mesmo 1880, que, sen dúbida, suscitou en Rosalía algunha reconsideración: a aparición dun gran libro, Aires da miña terra, dun gran poeta. Viuno moi ben, anos despois, o propio Murguía:

Mas llegó el momento en que herida de muerte la autora de Cantares gallegos, como quien se despide de lo que más amaba, dio a la prensa Follas novas diciendo que ya no 
escribiría más versos en la lengua materna. Era esto en el año 1880, año de bendición para las letras de Galicia, pues a un tiempo vieron la luz Follas novas y Aires da miña terra de nuestro inmortal Curros Enríquez. Y de este modo al astro que declinaba vino a sustituír el que asomaba poderoso en el horizonte, y el austero, el rudo, el cálido estro del nuevo poeta llenó de golpe el vacío que dejaba la que no tardó mucho en encontrar su descanso. Fueron dos éxitos que conmovieron la vida literaria de Galicia, dos libros distintos y un mismo empeño, fruto de dos almas condenadas a un mismo trabajo, a una misma muerte y a una misma gloria ${ }^{28}$.

Carecemos de textos (públicos ou privados) nos que Rosalía mencione a Curros e non sabemos, por tanto, que chegou a pensar de Aires da miña terra e da peculiar e polémica musa do seu autor. Cabe supoñer, en calquera caso, que Rosalía percibiu no insólito poemario de Curros un reforzo na construción do discurso literario galego. Por tanto, dúas trabes de ouro como Follas e Aires deberían disuadila a renunciar. Ignoramos que pensaba, xa en 1881, antes do suceso que suscitou a carta ó seu home na que lle comunica, en termos contundentes, a decisión de renunciar a escribir en galego. Vaiamos, pois, ós feitos que coñecemos.

Rosalía publica na primavera de 1881 un longo artigo nun periódico madrileño, en El Imparcial, na sección «Los lunes de "El Imparcial”". Titulábase "Costumbres gallegas» e apareceu en dúas entregas: o 28 de marzo e o 4 de abril. $\mathrm{O}$ texto, exhumado por Fermín Bouza Brey no ano 195529, é un canto en prosa, prodixioso en non poucos fragmentos, á beleza das paisaxes galegas e ás virtudes das súas xentes, canto que recorda, case ó pé da letra ás veces, o prólogo de Cantares gallegos. Cando Rosalía, en 1863, se refire a «algunhas das nosas poéticas costumes [que] inda conservan certa frescura patriarcal e primitiva», está preludiando observacións de 1881 formuladas case que coas mesmas palabras («[...] costumbres [...] impregnadas del espíritu patriarcal y llenos de la bondad de una raza [...]»). De catro capítulos consta o artigo, tres deles centrados na «laudatio» das nosas paisaxes e das nosas xentes. Ó longo do texto, ó mencionar as virtudes das nosas xentes, pon o acento nunha, a da hospitalidade, excelsa entre os habitantes da montaña e os das ribeiras, quizais un pouco máis entre estes. 
Vai ser ó final do capítulo onde Rosalía menciona e describe unha forma de hospitalidade que ela mesma cualifica de «estraña». Preséntaa e descríbea nos tres últimos parágrafos do artigo nestes termos:

La idea de que el padre, el hijo o el esposo pueden andar errantes y perdidos por inhospitalarias tierras o yermas soledades, contribuye, por otra parte, hasta tal punto a aumentar los compasivos instintos de aquellas gentes, que bien puede decirse llegan en esto a lo inverosímil e increíble. Lugares hay entre aquellos pueblecillos en donde se guardan creencias que no sabemos existan en ninguna otra parte, y que recuerdan la manera con que algunos pueblos primitivos llegaron a ejercer la hospitalidad, sin que acertemos a adivinar cómo, a través de los siglos, pudo conservarse entre nosotros este resto vivo de tan remotas costumbres.

Entre algunas gentes tiénese allí por obra caritativa y meritoria el que, si algún marino que permaneció por largo tiempo sin tocar tierra, llega a desembarcar en un paraje donde toda mujer es honrada, la esposa, hija o hermano pertenecientes a la familia, en cuya casa el forastero haya de encontrar albergue, le permita por espacio de una noche ocupar un lugar en el mismo lecho. El marino puede alejarse después sin creerse en nada ligado a la que, cumpliendo a su manera un acto humanitario, se sacrificó hasta tal extremo por llevar a cabo los deberes de la hospitalidad.

Tan extraña como a nosotros debe parecerles a nuestros lectores semejante costumbre, pero por esto mismo no hemos vacilado en darla a conocer, considerando que la buena intención que entraña, así ha de salvar en el concepto ajeno a los que llegan en su generosidad con el forastero a extremos tales como a nosotros el sentimiento que ha guiado nuestra pluma al escribir este artículo.

Na citada edición de Bouza-Brey hai unha nota que convén reproducir:

En el Cuestionario del Folklore gallego, cap. V, se pregunta: «¿Existe la prostitución hospitalaria de que habló Rosalía de Castro, o sea, la costumbre que al regresar el marino de un largo viaje se le ofrezca la hija o hermana del que le hospeda?».

Así pois, o Cuestionario da sociedade El Folklore Gallego (A Coruña, 1884) faise eco do artigo de Rosalía tres anos despois da súa publicación. Está claro que 
os redactores desa enquisa non teñen outra documentación, o que aínda acontece hoxe entre os nosos antropólogos. Sempre nos sorprendeu que os libros e as revistas do XIX de temas máis ou menos etnográficos non fixesen a menor alusión a este caso de "prostitución hospitalaria», denominación que, por outra parte, non nos parece afortunada. Repárese que non hai diñeiro polo medio e que a propia Rosalía esmérase en sinalar os aspectos positivos desta relación sexual en principio pecaminosa: que as xentes aquelas téñena "por obra caritativa y meritoria» e que a muller que se sacrificou cumpriu «a su manera un acto humanitario» a prol da «hospitalidad».

Sabemos por un traballo de Juan Naya que unha parte da prensa galega alporizouse con Rosalía por revelar un costume, na súa opinión, indigno. Eu penso que este alporizamento debeuse non só á revelación do feito senón tamén á actitude un tanto comprensiva de Rosalía. Os detractores, que agardaban una actitude admonitoria verdadeiramente tridentina, carecían de sensibilidade para detectar a sutileza humanística da cronista.

Ninguén exhumou as controversias que o artigo de Rosalía suscitou nalgúns periódicos galegos. Estamos hoxe como estabamos en 1953 (hai sesenta anos), cando Juan Naya Pérez exhumou nos Inéditos de Rosalia unha páxina da nosa escritora da que reproducimos as primeiras liñas:

He leído el artículo de El Anunciador y las líneas de La Concordia de Vigo a que se refiere la costumbre que desgraciadamente aluden con motivo de mi artículo de El Imparcial. Puede el erudito redactor de El Anunciador añadir esta nota más a las de la India. Si no le bastare, sepa asimismo que en Lima, por los años de 30 a 45, hacían lo mismo los criollos con los españoles que allí llegaban. Algo podía añadir, pero no lo merecen ni el fondo ni la forma de los insultos que con tal motivo se me han dirigido (p. 96).

Así as cousas, Rosalía escribe desde Lestrove, o 26 de xullo de 1881, unha carta ó seu home que é indispensable reproducir case enteira:

Mi querido Manolo:

Te he escrito ayer, pero vuelvo a hacerlo hoy deprisa para decirte únicamente que me extrańa que insistas todavía en que escriba un nuevo tomo de versos en dialecto gallego. No siendo porque lo apurado de las circunstancias me obligaran imperiosamente a ello, 
dado caso que el editor aceptase las condiciones que te dije, ni por tres, ni por seis, ni por nueve mil reales volveré a escribir nada en nuestro dialecto, ni acaso tampoco a ocuparme de nada que a nuestro país concierna. Con lo cual no perderá nada, pero yo perderé mucho menos todavía.

Se atreven a decir que es fuerza que me rehabilite ante Galicia. ¿Rehabilitarme de qué? ¿De haber hecho todo lo que en mí cupo por su engrandecimiento? El país sí que es el que tiene que rehabilitarse para con los escritores, a quienes, aun cuando no sea más que por la buena fe y entusiasmo con que por él han trabajado, les deben una estimación y respecto que no saben darles, y que guardan para lo que no quiero ahora mentar. ¿Qué algarada ha sido esa que en contra mía han levantado cuando es notorio el amor que a mi tierra profeso? Aun dado el caso (que niego) de que yo hubiese realmente pecado, por lo que toca al artículo en cuestión, ¿era aquello suficiente para arrojar un sambenito sobre la reputación literaria grande o pequeña de cualquier escritor que hubiese dado siempre probadas muestras de amor patrio, como creo yo haberlas dado? No; esto puede decirse sencillamente, mala fe o falta absoluta no sólo de consideración y gratitud, sino también de criterio. Pues bien, el país que así trata a los suyos no merece que aquéllos que tales ofensas reciben vuelvan a herir la susceptibilidad de sus compatariotas con sus escritos malos o buenos. Y en tanto, ya que tan dañada intención han encontrado en lo que narré para dar a conocer (y no para alabarla ni censurarla) una costumbre antiquísima, y de la cual aún quedaba algún resto en nuestro país, puede consolarse leyendo la estadística por lo que toca a cierta cuestión que han sacado a relucir ciertos periódicos escandalizados con mi artículo. Si se arremetiese contra la estadística sería mejor, a ver si así lograban borrar lo que es peor mil veces que lo que en mí han censurado tan bravamente.

Hazle, pues, presente al editor que, pese a la mala opinión de que al presente gozo, ha tenido a bien acordarse de mí, lo cual le agradezco, mi resolución de no volver a coger la pluma para nada que pertenezca a este país, ni menos escribir en gallego, de una vez que a él no le conviene aceptar las condiciones que le he propuesto. No quiero volver a escandalizar a mis paisanos [...].

Todo fai supoñer que Murguía insistía unha e outra vez para que Rosalía non deixase de escribir en galego, teima que, quizais, se iniciou no verán de 1880 , apenas editado Follas novas. Ela, despois da polémica periodística, despois dos «insultos», non está disposta a compracelo, se ben hai un dato na carta que deixa unha porta aberta: «No siendo que lo apurado de las circunstancias me obligaran 
imperiosamente a ello, dado caso que el editor aceptase las condiciones que te dije, ni por tres, ni por seis, ni por nueve mil reales volveré a escribir en nuestro dialecto, ni acaso tampoco a ocuparme de nada que a nuestro país concierna». As «circunstancias» son, sen dúbida, as económicas. Por tanto, se o editor acorda unha cantidade superior á indicada, só nese caso escribiría un novo libro. Rosalía volve sobre o asunto nas liñas finais: «[...] ni menos escribir en gallego, de una vez que a él no le conviene aceptar las condiciones que le he propuesto».

A decisión, por tanto, non era irrevogable. Rosalía, en efecto, renunciara a facer poesía en galego, pero, nesta altura, malia os «insultos», estaba disposta a reconsiderar o seu propósito se o editor melloraba notablemente a oferta económica. Fosen ou non imperiosas as circunstancias económicas, o certo é que o editor non aceptou as condicións propostas pola escritora. Doída pola actitude dunha parte da prensa galega, Rosalía dimite.

Supoño que Rosalía era moi consciente de que os seus detractores eran poucos e, alén diso, pouco significativos, pois non temos noticia de que as voces importantes de Galicia, galeguistas ou non, insultasen a nosa escritora. En realidade, chovía sobre mollado: ela, sen aldraxes polo medio, xa decidira, en marzo de 1880, renunciar á súa carreira de poeta en lingua galega, renuncia que tińa que ver, sen dúbida, co horizonte limitado atribuíble, na súa concepción, ó discurso literario galego, tal como explicamos ut supra. Se esta concepción a estaba revisando despois da lectura de Aires da miña terra, é algo que se ignora. Sexa como for, a polémica periodística de 1881 afirmouna no seu vello propósito, se ben —cómpre repetilo- só determinadas circunstancias económicas (estreitezas familiares e oferta do editor) condicionarían outra opción. Cómpre engadir que a reacción de Rosalía é un pouco infantil, sobre todo — se deixamos o «dialecto»— cando enuncia que non volvería «acaso tampoco a ocuparme de nada que a nuestro país concierna», «ameaza» que formula con máis contundencia ó final da carta: «[...] mi resolución de no volver a coger la pluma para nada que pertenezca a este país». Reacción primaria, impropia da súa entidade moral e literaria, por pouco que ela mesma valorase o significado da súa obra.

¿Cal foi, nas mesmas datas, a reacción de Murguía? Xa convencido da negativa de Rosalía, actúa, polo menos nunha ocasión, coma ela. Cando Francisco Portela Pérez se dirixe a el, solicitando autorización para incluír un poema da escritora 
nunha antoloxía ${ }^{30}$, contéstalle que Rosalía «desearía [...] por razones puramente personales, que no se insertase nada suyo en dicho libro», se ben ó final fai esta concesión:

[...] si esto pudiera parecer a $\mathrm{Vd}$. un desaire [...], puede desde luego incluír en el volumen dicho la poesía que Vd. indica, una vez que su autora está dispuesta a sufrir en toda su extensión la tiranía que en nombre de Galicia se ejerce a todas horas y con todos los motivos sobre aquellos de sus hijos que, desgraciadamente para ellos, escriben alguna cosa31.

Consumou a dimisión Rosalía de Castro? Así foi. Desde 1880, Rosalía só publica textos en castelán, entre eles a novela El primer loco (1881), xénero, para ela, só realizable en castelán, tamén, nalgunha medida, por razóns económicas, sempre moi presentes no fogar Murguía-Rosalía, nunca verdadeiramente farturento. En 1884 publica un libro de poemas en castelán, En las orillas del Sar, elección idiomática allea a consideracións de índole económica se nos atemos ós pronunciamentos emitidos pola escritora en 1880 e 1881. En las orillas del Sar é, no "curriculum» poético de Rosalía, o seu libro testamentario. Libro radical onde os haxa, é o poemario onde Rosalía se mergulla no seu desamparo existencial. Autobiografía atormentada, tráxica, xa preludiada nalgúns poemas de Follas novas. Rosalía, pois, é poeta universal — poeta da condición humana na súa dimensión radical - tanto en galego coma en castelán. Equivócase, en parte, Unamuno cando expón esta dicotomía:

Lo más personal, lo más íntimo, lo más subjetivo [...] de Rosalía, hay que ir a buscarlo a sus poesías castellanas de En las orillas el Sar. Cuando quiere hablar ella y no hacer hablar a su pueblo, cuando quiere quejarse ella, Rosalía, y no la gallega, habla y se queja en castellano ¡Y qué hondamente! [...] El alma que recibió de su pueblo, se la dio a su pueblo en la lengua materna y maternal de éste, pero para su espíritu personal y propio,

30 Colección de poesías gallegas d'algúns autores, Pontevedra, 1882.

31 Exhumou esta carta Victoria Álvarez Ruiz de Ojeda no seu artigo «Sobre a “demisión” de Rosalía: unha carta inédita de Manuel Murguía», Grial, 131, 1996, pp. 389-394. Na Colección non figura ningún poema de Rosalía. 
varonil y recio, para su yo, búscase una estatua en castellano, porque la estatua que ella se buscó fue en los broncíneos versos de En las orillas del $\mathrm{Sar}^{2}$.

No que se equivoca Unamuno é en omitir Follas novas, libro que en non poucos dos seus poemas merece a caracterización e a valoración que fai de En las orillas del Sar.

Neste libro, Rosalía, unha escritora universal — que fala para todos- non omite, nalgunhas páxinas excelsas, certas realidades galegas que a magoaban desde había tempo. Figuran no libro dous poemas tan significativos como valiosos: «Los robles» e «Volved». No primeiro, sobre a tala dos carballos, hai versos decididamente patrióticos ("y yo no quiero que mi patria muera») e, no segundo, volve ó vello tema da emigración, agora xa con outros matices («xa que non tendes sitio na hostigada terra, volvede!»).

Se se me permite a expresión, Rosalía, en 1884, dimite a medias: renuncia ó idioma de Cantares e de Follas pero non se desentende de determinados problemas do país, e aí están, entre outros, os dous excelsos e longos poemas citados. Non cumpriu, pois, o anunciado na carta de 1881: «[...] no volver a coger la pluma para nada que pertenezca a este país» ${ }^{33}$.

32 «En las orillas del Sar», El Eco de Santiago, núm. extraordinario, 1917.

33 Sobre a carta, a dimisión, etc. v. o meu libro Rosalía de Castro, Madrid, Júcar, 1972, pp. 88-106. 